\title{
AGRARIAN ANARCHISM IN ANDALUSIA
}

\author{
DOCUMENTS ON THE MANO NEGRA
}

In 1883 the Spanish public became acquainted with a series of crimes committed in the provinces of Cádiz and Sevilla by the Mano Negra. Rooted in the agrarian South, this organization was accused of attempting to bring down the Spanish government and to sweep away the landed aristocracy of Andalusia, even by resorting to the most extreme and violent means. ${ }^{1}$

Organized as a rural secret society, it became the public image of what a workers' organization could do under the influence of the International Working Men's Association (IWMA) and of the anarchist ideology that preached land reform and the transformation of the existing social order. Accused of perpetrating a series of common crimes against the property and lives of landowners and fellow workers, it was easily taken for a "secret association of kidnappers, murderers and arsonists". ${ }^{2}$ The ruling groups, dutifully aided by the Guardia

1 There is no single study devoted to the Mano Negra. Neither at the time of the trials, when the issue was still too alive, nor later, when it was reopened by the anarchist group of Tierra y Libertad (Madrid), El Corsario (Valencia), the French La Dépêche and Temps Nouveaux, in 1902-03, to free the accused criminals still in jail, was there any attempt by historians to work extensively on the matter. Only the outstanding scholar of agrarian Córdoba, Juan Díaz del Moral, realized that the problem was rather complex but the sources too inadequate to carry out a more exhaustive and dispassionate study. (See: Historia de las agitaciones campesinas andaluzas. Córdoba, Madrid, 1929, Ch. 6. This book, which had been out of print for a long time has been made available recently in an abridged edition by Alianza Editorial, Madrid, 1967). This article is part of a study I am preparing on the origins of Spanish anarchism (1868-1884). Besides my own research on this problem, the only other study that $\mathrm{I}$ know of is a $\mathrm{Ph}$.D. thesis for Columbia University which Mr Glen Waggoner is currently preparing on the "Black Hand: The Anarchist Movement in Andalusia, 1881-1892". (In the following notes we will refer to the Mano Negra as MN and the International Working Men's Association as the IWMA.)

2 From El Globo, Madrid, quoted by El Guadalete, Jerez, Feb. 20, 1883. See also the following Madrid newspapers for similar and complementary in formation: El Imparcial, the Liberal, the Correo, La Correspondencia, etc. 
Civil, and openly supported by the government of Sagasta made it their job to suppress all protests and menaces with relentless energy. In a few weeks the jails in the main Andalusian cities and towns were crowded with hundreds of workers arrested under the charge of belonging to the highly-feared movement. ${ }^{1}$ No proof was necessary; suspicion by a landlord, a magistrate or a Civil Guard, or the merest suggestion from anybody else was enough evidence for a jornalero or any politically-minded person to be imprisoned in one of the local jails in the South. In less than a month the figures jumped from 300 prisoners in Jerez and Cádiz (Feb. 27, 1883) to more than 2000 in Cádiz (March 14) and more than 3000 in Jerez (March 3). Though these figures may be inexact, the proportions speak for themselves. ${ }^{2}$

It soon became very clear that had the Mano Negra had the support of as many members as people imprisoned, it would never have been a secret society but a public political party. It was quite obvious that the government and the landed groups were abusing their power. Persecutions became the arbitrary means used by the ruling classes to suppress any demonstration of public dissatisfaction and to silence any

1 See the daily reports of the Spanish press at the time; the Liberal reported, on Feb. 24, 1883, that there were 35 people imprisoned in Arrabal (sic! Arahal?), 35 in Marchena, more than 360 in Jerez and Cádiz, and many others in Arcos, Osuna, Balbuena, Villamartín, Villanueva de la Serena, etc. El Porvenir, Sevilla, quotes from El Imparcial that more than 200 members of the Spanish Federation of Workers were imprisoned in Cádiz, as well as in Jardilla, el Arahal, Jerez, etc.

2 Figures from El Porvenir, Sevilla. Due to the lack of access to other documents of this criminal case it is impossible to make an accurate study of the organization of the membership of this society. Yet, through the information in newspapers of the time it is possible to affirm that the membership came from people of the most diverse origins, as happened in the IWMA itself. "The 360 prisoners who were recently brought into Xeres by the police were not only of all ages, but included small landholders as well as simple peasants and smugglers." (The Nation, N.Y., April 5, 1883) The local newspapers reported other members: reserve soldiers and low-ranking officers (El Guadalete, March 1, 1883 and The Saturday Review, August 18, 1883, p. 196), civil guards (El Imparcial, March 13, 1883), andalusian peddlers, smugglers and gypsies (ibid., March 6), and landowners "of rural properties of certain wealth, and others gifted with a rather uncommon learning, and of irreproachable conduct and good nature" (El Porvenir, March 6, 1883. See also El Imparcial, March 1, El Guadalete, March 6, El Porvenir, March 11). There were also many women involved; one of them, Isabel Luna, was known as "the Louise Michel of Benaocaz" (La Andalucía and El Porvenir, March 14, 1883). Among those gifted with "a rather uncommon learning", was Juan Ruiz, a school teacher in the Jerez region, believed to be one of the heads of the MN, "the most intelligent and active leader" (El Guadalete, March 2, 1883; cf. El Porvenir, March 3 and El Imparcial, March 4). Also among the suspects was Antonio Moreno Merino, druggist, who admitted his connection with the secret society as an "honorary member" (El Imparcial, March 13, 1883). 
political activity among rural workers. What was meant to punish the authors of the Crimes at Cuatro Caminos, Parrilla, etc., turned into a war of extermination against the IWMA in Andalusia: ${ }^{1}$

"by the very fact that the assassins of the Blanco de Benaocaz and the innkeeper Nuñez belong to the International, all the federates, associates and those engaged in each of the innumerable socialist centers that follow the International or the statutes of Sevilla, are undoubtedly considered accomplices and, maybe, co-authors of the vile crimes committed in Jerez and Arcos. [...] Are the crimes committed in Jerez, Arcos and nearby areas being punished, or is the action of social defense extending to persecute as accomplices all those who have aligned themselves with active socialism?"2

The Spanish Regional Federation of the IWMA was banned in 1874, forcing many of its most active members to go underground. After the fall of the conservative government of Cánovas, in 1881, the International was allowed to resume its political life under the new name of Federation of Workers of the Spanish Region. The ban was lifted much to the distress of the most powerful and traditional ruling groups, the Church, the landed oligarchy and the right-wing political parties. It was soon obvious that it was these groups who were interested in stressing the ties between what they considered a criminal association and the much feared anarchist movement, recently revived with even greater militancy and numerical strength than before. The vast amount of documentary evidence gathered by the Spanish authorities to convict the accused criminals was quickly turned to the advantage of the government, which used it to allege the direct dependence of the Mano Negra on the Spanish Federation of the IWMA. ${ }^{3}$

1 "...the number of members rose to 7,000 first, then to 12,000 , later it was over 20,000 and recently the figure has been touching on 49,000 . The series of imprisonments which increases at an extraordinary pace, the arrest of federates in places relatively far from the scene of the crimes, and the ever-increasing number of members of secret societies to about forty thousand, makes one believe that both public opinion and government agents have poured a huge army of men into the prosecution of a common criminal cause. [...] One can hardly call an organization which a few months ago was celebrating a public and well-attended congress in Sevilla a secret society, and which after discussing its statutes and preaching collectivism and anarchy, gave a vote of thanks to the Governor of the province [...] for his extremely law-abiding and liberal conduct towards them." El Porvenir, March 10, 1883.

Ibid., pp. 1-2.

${ }^{3}$ El Guadalete, Jerez, Feb. 20, 1883 reproduces a telegram sent by the lieutenant of the Civil Guard, at Arcos, to the Governor of Cádiz: "Great discoveries about criminal society; multiple imprisonments; taking possession of lists and signed documents of the Association [IWMA?]." In March the seal of the 
On the other hand, fearing the repression and consequent banning of their activities, if such a connection were established, the Federation of Workers was quick to disavow any connection with the extremist agrarian group. Furthermore, they condemned any organization which resorted to common criminal acts to attain their goals:

“...we must repeat again that our Federation has never been a party to robbery, arson, kidnapping nor assassination; we have never given support nor do we support the Mano Negra, [...] nor any secret society whose object is the perpetration of common crimes [...] He who steals will always be a thief, he who kidnaps will always be a kidnapper and he who assassinates will always be an assassin, be it in the present-day society or in the society of the future. The Spanish Federation neither supports nor has among its members thieves, kidnappers or assassins..."1

They even denied the existence of such a seditious group and accused the government of inventing a revolutionary organization when all that really existed was a handful of criminal and demented peasants with no specific political ideas or intentions: "... the Mano Negra is not a society of workers but, perhaps, of deluded people, embracing unattainable ideas, and its ranks consist of criminals rather than workers..."2 This invention, they claimed, was another weapon used by

\footnotetext{
"Working Men's Association, Agricultural section" was found; this was enough proof for the authorities to claim that the IWMA in Spain is the sole "association responsible for the actions of the Mano Negra", El Porvenir, March 3, 1883. In 1884, the conservative groups were still asking for further drastic measures against the socialist press. La Union, a conservative newspaper, demanded that the editors of the republican El Motin, the freethinking Las Dominicales del Libre Pensamiento and the anarchist Revista Social be executed by garrotte (cf. La Federación Igualadina, June 7, 1884, p. 2).

1 "Declaración de la Comisión Federal española", March, 1883, reproduced by Anselmo Lorenzo, El Proletariado militante, ed. Vértice, México, n.d., pp. 43637.

2 The "Manifiesto de la Comisión Federal de la Federación de Trabajadores de la Región Española" opens: "When the bourgeois press, ranging from the most reactionary to the most radical, publishes frightful accounts about certain crimes, which, were they true, no honorable man would defend; when the aforementioned press publishes data and news concerning secret associations whose main object is arson, robbery and assassination; [..] we would certainly be neglecting our duty if we did not PROTEST against the miserable slanders of those whitecollar workers who expect the Courts or the Government, because of their false accusations, to consider 70,000 workers co-participant in the crimes which we are the first to censor, since it is quite likely that their victims may be honorable and trustworthy proletarians", cf. A. Lorenzo, op. cit., pp. 434-36. See also the "Protesta de la sociedad de albañiles y demás obreros pertenecientes al oficio", Madrid, March 4, 1883, published by the Revista Social, March 8, 1883, p. 4,
} 
the bourgeoisie to destroy the true workers' associations which, they insisted, only fought in the open political arena. This attitude not only explains the Federation's desire to protect the movement from any further reprisals but, as we shall see further on, it reflects a deep gap between the agrarian interests of the South and the interests of industrial workers in urban areas.

As a result of this, the Mano Negra was attacked by the contending groups. By disengaging themselves from any support of this secret society the Spanish Regional Federation tried not only to protect itself but contributed unconsciously to the surrender of the Mano Negra to the Andalusian landed classes, which were anxious to exterminate the seeds of revolution. The central issues of agrarian discontent and misery were overshadowed by the more polemic struggle of the two wings in the Spanish political spectrum. Neither side was really interested in explaining or understanding the motives of and the questions posed by the Mano Negra, but dealt with it in order to accuse the other: either it represented a definite proof of dangerous political radicalism which had to be eliminated or it was a proof of governmental restriction of liberties and an example of working-class discontent, exploitation and poverty.

Ever since its beginning, the question of the Mano Negra has been regarded with a polemical interest rather than with historical objectivity. "Bourgeois" historians have constantly claimed that the organization was an active agent of the Regional Federation and as despicable, criminal and lawless as the IWMA itself. Anarchist and liberal historians, on the other hand, have denied all connections with what they termed a group of "perturbadores". Yet, the question of what the Mano Negra really was has not been answered. ${ }^{1}$

which states among other things that "...the Mano Negra [...] cannot be a workers' association but, maybe, a society of lunatics supporting unattainable ideas, and with more criminals in its ranks than workers."

1 Even today the militant historians of anarchism deny any connection between the IWMA and the MN and claim it was an official invention. Diego Abad de Santillán, for instance, questions its existance: "Did the Mano Negra really exist? At least the legend was created and provided a welcome excuse to justify atrocious anti-proletarian repressions in Andalusia. It did not exist as a structured organism, nor as a part of the anarchist or workers movements, since no proof has remained of its existence, but it did exist as a belief of the reactionary press." (Contribución a la historia del movimiento obrero, Cajica, Puebla, Mex., 1962, p. 321) Other writers not connected with the anarchist movement also deny its existence: F. G. Bruguera, Histoire contemporaine de l'Espagne, 1789-1950, Ophrys, Paris, 1953, pp. 311ff.; James Joll, The Anarchists, N.Y., 1964, Ch.IX, p. 232; Manuel Tuñón de Lara, La España del siglo XIX (1808-1914), Paris, 1961. Others, like Melchor Fernández Almagro (Historia política de la España contemporánea, Pegaso, Madrid, 1956, pp. 393-97), say that the MN "carried 
One of the main reasons for this historiographical underestimation has been the apparent loss of all the documentary evidence gathered by the Spanish authorities for the trials. These documents, which according to a reporter amounted to more than 6000 pages, had the status of "reservados" and were kept either at the Audiencia at Jerez or sent to the Ministry of War in Madrid. ${ }^{1}$ In the former case they seem to have been lost because they were either destroyed or misplaced when the Jerez Audiencia disappeared as such and its jurisdiction was transferred to that of Cádiz. In the latter, there are also some grounds for assuming that a considerable portion of the material was destroyed in Madrid or else that it is still buried in secret government archives. ${ }^{2}$ This situation was changed by our finding one of the most important documents of the case, the "Regulations and Statutes of the Mano Negra. A society of the poor against their thieves and executioners". ${ }^{3}$ This was one of the decisive proofs used by the authorities to assert the connection between that secret society and the Spanish IWMA in view of its goals, language and, as we will see further on, particularly because of the reference made in the first paragraph of the Statutes to the suppression of the International and the consequent need for all Spanish revolutionaries to reorganize secretly.

to its utmost consequences the doctrine and orders of the Spanish Regional Federation of the IWMA [whose] poisoned seed [took root and blossomed] in a terrible way" (p. 393).

1 According to one of the reporters from Jerez, by March, 1883 the evidence gathered amounted to more than 6000 pages: "it resembles an Indian poem with neither beginning nor end, the criminals underwent more metamorphoses than those of Buddha [...] As part of the documentation there are the said statutes [of the MN], very curious information and sentences of punishments, issues of a socialist journal and other papers" (La Andalucia, March 1st, 1883).

" This "loss" of documentation is a fact that must be faced at sometime or another by most historians of modern Spain. During the Civil War many Municipal archives were burned; afterwards the new regime proceeded to anathematize and destroy all papers dealing with socialist and masonic movements or to bury them in a secret archive in Salamanca which had been specially built for that very purpose. This archive, as well as other government archives, such as those of Departments of War, the Interior, etc., are inaccessible to outsiders. However, a great number of local and provincial archives may be consulted by the historian. Although most of them have no good catalogues or systems of cataloguing, someone willing to spend enough time patiently researching might well obtain tangible results. This holds true for most Andalusian municipal archives and certain private ones.

${ }^{3}$ I would like to express my gratitude to Prof. Iris Zavala, who found this document in the Archivo de Palacio, Madrid, during her own research on an earlier period of Spanish history and was kind enough to have it copied for me. This document is part of Legajo No 10,077 of the "Secretaría Particular de S.M.". 
To our knowledge this is the first time that the document which is appended to this article is published in its entirety; it was mentioned and even quoted and misquoted by the press at the time of the trials but never reproduced in full. ${ }^{1}$ The fact that nobody seems to have seen it in its entirety left the impression among historians that it did not exist and that it was another forged piece of evidence hastily invented to win a case. Now that the existence of the Mano Negra is a historical problem and not a political issue any longer, we should try to reevaluate the question with fresh evidence to which this document will indeed contribute in no small degree.

In 1883 the "crimes of the Mano Negra" were the excuse used by the government to deal a severe blow to all agrarian radicalism. The pretext was a few common crimes which were never really solved and it resulted in the ruthless suppression of any organized rural political group and a greater and more determined oppression by the Andalusian landowners of their discontented and insubordinate peasants and peons. If one were to reread any of the lawsuits against the Mano Negra, ${ }^{2}$ the most striking discovery would be that although a great deal of legal work went on and though the verdict of the Supreme Court ratified that of the Jerez Audiencia (which had sent several people to jail or sentenced them to death), there was no conclusive evidence against the accused. The result of the case was extremely ambiguous and the only thing that seemed to emerge clearly was the existence of agrarian agitation and disturbances and of secret societies ready to exploit this unrest.

One of the pieces of proof brought against the convicted workers was this document. However, contrary to what has been thought, it was not originally related to these crimes but was unearthed from a previous case against illegal political associations ("Asociaciones

1 See Miguel Morayta, Historia general de España, F. González Rojas, Madrid, 1896, Vol. IX, pp. 1201-02; F. Pi y Margall: Historia de España en el siglo XIX, Vol. VI, pp. 224-25; La Andalucía, Sevilla, Feb. 27, 1883; El Porvenir, Sevilla, Feb. 28, 1883, etc.

2 Cf. Agustín Sáez Domingo, Procesos célebres. Crónicas de tribunales españoles, Cuaderno IX: "Procesos del Salar y la Mano Negra, recursos de casación", in: Revista de Legislación, Madrid, 1884, pp. 65-232; Causas célebres llamadas de la Mano Negra, publicadas en el Diario de Cádiz. Audiencia de Jerez de la Frontera. El crimen del Puerto. El crimen de Arcos. Asesinato del Blanco de Benaocaz, Cádiz, 1883, 156 pp.; Los procesos de la Mano Negra. Audiencia de Jerez de la Frontera. Proceso seguido a Cristóbal Durán Gil y Antonio Jaime Domínguez por asesinato de Fernando Olivera, Revista de Legislación, Madrid 1883, 74 pp. 
ilícitas"), and had been in the hands of the Spanish authorities at least since $1879 .{ }^{1}$ Furthermore, at the time of the trials reports in the press also revealed that these Regulations and Statutes were aiready known in 1878:

"In a trial begun in Jerez in August, 1878 by judge Fajano, the first mention can be found of an association of malefactors organized with the purpose of committing robberies, kidnappings and acts of vengeance. The authorities then came into possession of a manuscript notebook, of poor penmanship and worst spelling, which stated the aims of a society called The upright poor against the tyrannical rich. These were the statutes of the Mano Negra."2

In its issue of March 3,1883, La Andalucia provided the additional information that according to Senator Moreno Rodriguez in a speech made on February 28, the Mano Negra had been no secret to the government as far back as 1875 . Despite this want of a precise date, it is a very significant fact that by the mid- or late-seventies the existence of this secret society and its executive section, the Tribunal Popular, were already known to the authorities. Yet, although the program was in their hands, the actual machinery of the Mano Negra was still unknown. It seems quite probable that our copy of 1882 , as well as another one we found in the Municipal Archive of Jerez de la Frontera, dated in $1881,{ }^{3}$ were made from the original draft of the Regulations drawn up sometime in the seventies.

The assumption that the Mano Negra was founded in one of these years fits well into the chronology of the opening statement of the Statutes, which makes reference to the years between 1874 and 1881 when the IWMA was banished and only through some kind of secret organization could any type of political activity take place:

"As the IWMA was declared illegal by the bourgeois governments, thus preventing it from peacefully solving the social problems which must be resolved without further delay, it has been forced

1 A. Sáez Domíngo, op. cit., pp. 92 and 188.

${ }^{2}$ La Andalucía, March 1, 1883; cf. El Día, Feb. 2, and El Guadalete, March 1, 1883.

3 The document I found in the Archivo Municipal de Jerez de la Frontera, Legajo No 8, has as its title: "The Mano Negra. A society of the poor against their thieves and executioners. Europe. Nineteenth Century." This copy is not accompanied by any other document or information. Although some minor differences exist, the text remains basically the same except for article No 2 of the Statutes. The text in Jerez reads: "The object is: first, to preserve in all its strength the principles of the IWMA, and, secondly, to punish the crimes of the bourgeoisie and its subordinates by every possible means, be it by setting fire to property, knifing, poisoning, or any other way." The other difference 
to turn into a secret revolutionary organization in order to bring about the violent social revolution..."1

Since the crimes were committed in 1883 it would not have made much sense to have had this document forged with such an opening paragraph at a time when the IWMA was engaging, quite legally, in political activities again after the fall of Cánovas. That this document did not come to light at the time of its discovery in the 1870's but in the following decade must be attributed to the fact that during the years after the banishment of the International, although political trouble existed, the conservative regime had the situation under control. It was not until the more liberal cabinet of Sagasta took power and the Working Men's Association resumed its public activities in 1881, that it became necessary to resort to this outdated proof as a strong weapon to curb the gains of the new Federation of Workers and to crush all the social unrest that was growing in rural areas of Spain. ${ }^{2}$

In the letter which accompanies the document (see Appendix), García Cerunio, director of the Civil Guard, corroborates its early date when he informs the Secretary of War of the investigations made by a

is in the title: instead of "Andalusia", the Jerez version has "Europe. Nineteenth Century". This detail may remind us of other similar movements that were active in other countries such as Italy, Ireland, France and Russia. There are rather striking coincidences, for example, between the agrarian troubles of Ireland at the time of the Agrarian League, the Fenians or Captain Moonlight's terrorism, and those of Andalusia. These coincidences were often underlined by the newspapers of that time. Le Révolté (Geneva) observed in 1879 the close parallelism between Russia (August 9), Ireland (November 29) and Spain. A year later it commented that "Les nouvelles d'Irlande ne cessent d'être pleines d'enseignements pour nos amis d'Espagne, d'Italie, de Russie. Ils prouvent que dans ce pays la solidarité n'est pas un vain mot et que pour agir il n'est pas nécessaire d'avoir des gros bataillons." (Oct. 17, 1880) In 1882, when the Lyon crimes took place, the Spanish government imprisoned several Andalusian anarchists accused of plotting against the State with the help of the Spanish IWMA and some Lyonaise anarchists; some Spaniards were also to be found among the active members in Lyon (Le Révolté, Nov. 25, 1882). References to these and similar cases were frequent at the time. Perhaps a more detailed study of the problem would lead to a better understanding of the relations between certain agrarian and terrorist movements in Europe and their connection with anarchist ideology and organizations.

1 See Appendix: Statutes, opening paragraph. Cf. below, p. 326, note 1 .

2 The economic crisis of 1879 sparked off a long series of uprisings and riots in all areas of the country. In Andalusia some of the cities which suffered from these disturbances were Arcos (El Imparcial, April 26, 1879), Cádiz (ibid., Jan. 12 and 13, 1879), Córdoba (ibid., April 27, 1879), Granada (ibid., April 24, 1879), Jerez (ibid., April 26, 1879), Puerto de Santa María (ibid., Jan. 13, 1879), Ronda (ibid., April 20-24, 1879), Sanlúcar (ibid., Feb. 15 and 16, 1879), Sevilla (ibid., May 11,1879 ). These were just a few of the innumerable signs of discontent in the South. 
subordinate about the activities of the International in Andalusia. The report concludes that "... this Socialist society has been well organized for a long time in the provinces which are under my jurisdiction...".

This problem of dates and the question of forgery can only be solved if, in regard to its authenticity, we let the material speak for itself. We will compare it to other similar anarchist documents, placing the problem in its proper historical perspective and context, and showing the continuous trend in the development of agrarian revolt and discontent in Andalusia.

Continual uprisings in one or another Andalusian village and town throughout the 19th century reveal the existence of groups which tried to channel discontent into political means of expression. Carbonari organizations and republican ideas played an active role in orienting popular dissatisfaction into radical political action. Although these groups had existed in Spain since the years which immediately followed the Wars of Independence, it wasn't until the 1840's that they became powerful enemies of the monarchy. Under the direction of revolutionaries such as Fernando Garrido, Sixto Cámara, Abdón Terradas, Ordax Avecilla, Ceferino Tresserra they were to be credited with most of the revolts which shook the foundations of the government and brought to the surface the deep-rooted discontent of the lower classes in marginal areas of the country. The power of these republican secret societies can be observed during the "Bienio liberal"; in the insurrection of 1857 in Málaga, Sevilla, Arahal, and other Andalusian towns; at the time of the revolt of 1859 , during which Sixto Cámara lost his life; in 1861, when Pérez del Álamo's rebellion in Loja and neighboring areas inspired from ten to twenty thousand people to rise in arms. ${ }^{2}$ Active carbonari like Garrido or Conrado Roure estimated that the society had between 40,000 and 80,000 members in the early 1860 's,

1 See Appendix, letter by Tomás García Cerunio. We know nothing about the author of this letter nor about the "Colonel Subinspector of the Fourth Corps" of the Civil Guard. Further investigation into the archives of the Ministry of War and of the Civil Guard would probably shed more light on this problem; so far these have remained inaccessible.

2 There is no thorough study of the development of agrarian movements in Southern Spain during the first half of the nineteenth century. Diaz del Moral (op. cit., Chapters 4 and 5) refers to some of them. I have also dealt with this problem in Chapters 1 and 2 of my doctoral dissertation (Princeton University, 1968), making use of references found in the press of the period and of documentation from Spanish archives. 
and was especially strong in the areas of Galicia and Andalusia. ${ }^{1}$ Even though the figures may be grossly exaggerated they underline the prevalent radicalism of the South. The influence of carbonari-type organizations and republican ideas continued well into the middle of the century. In Spain, as in the rest of Europe, these secret societies were the only channels of expression for the radical segments in the years preceding the birth of the First International. The republican heads of these conspiratorial movements, whose interests were those of the intellectual and revolutionary bourgeoisie, were mainly concerned with a political change but did little to create a social or economic consciousness in the Spanish worker and peasant. The revolutionary crowds which faithfully followed their leaders had only the faintest notion of their rights; they were mainly pushed by the vague hope of land distribution, the betterment of their wages and the freedom of labor and association. All these concessions, if they were granted at all, were special favors bestowed on the people from above rather than as the legitimate fruits of struggle at the bottom. ${ }^{2}$ The International

${ }^{1}$ Cf. Fernando Garrido, Historia del reinado del último Borbón en España, Salvador Manero, Barcelona, 1868, Vol. III, pp. 358ff. and 525ff.: "in Andalusia Carbonarism spread everywhere, in the city as well as in the countryside" (p. 525). Conrado Roure states in his Recuerdos de mi larga vida (Barcelona, 1925, Vol. I, pp. 232ff. and $257 \mathrm{ff}$.) that "towards 1863 , there were some 200 masonic lodges in Spain, with about 40,000 members" (p. 232). During 1820-23 the South of Spain, (mainly Cádiz, Sevilla and Córdoba) were the strongholds of the "exaltados" or radicals. It was in Málaga that the "comunero" Lucas Francisco Medialdúa wanted to establish the República Ibérica in 1821, and in 1823, another "exaltado", the deputy José Moreno Guerra, tried to proclaim a Republic in Cádiz (cf. José María Azcona: Clara-Rosa, masón y vizcaíno, Espasa-Calpe, Madrid, 1935, pp. 34-6 and 220-21). F.M. Hughes, in Revelations of Spain in 1845 (London, 1854), notices that "the South of Spain has been a considerable focus of Republicanism ever since the Constituent Cortes sat at Cádiz in 1812. [...] Freemasonry is mixed up with all these secret societies" (p. 260). The radicalism of the South is not found only among the intellectuals; the vast number of "exaltado" newspapers published during the Trienio (1820-23), suggest a wide range of readers. This is sustained by the information found in the Indice alfabético de todos los sujetos que han ocurrido a ser expontaneados ante D. Pedro Téllez por haber pertenecido a sociedades clandestinas, Archivo General de Palacio, in "Papeles reservados de Fernando VII", Vol. 67, where we see that a great number of the "comuneros" were not only landowners but, like the members of the MN half-a-century later, a cross-section of society.

${ }^{2}$ This special character of republican secret societies and movements was severely criticized by Karl Marx as early as 1850 . To him the conspirator becomes "a professional revolutionary" who loses sight of the social and economic goals of the revolution, cf. Schlomo Avineri, "Marx and the Intellectuals", in: Journal of the History of Ideas, XXVIII (2), 1967, pp. 269-277. Thirty years later the communist anarchists were also speaking in similar terms, cf. "Compte-rendu du 
injected fresh hopes and directives into the laboring classes, introducing concepts of class struggle and property redistribution to add to the strong republican and anti-centralist feelings.

The success of this ideology was such that in the years between its introduction in Spain, in 1868, and its official banishment, five years later, it laid the foundations for the most powerful Peninsular labor movement, with more than 20,000 members. With the suppression of the IWMA in 1874, and the resulting persecution of militant workers by the government, the need to establish secret organizations was strongly voiced among labor leaders as the most efficient means of survival and action until the time of the final Revolution, which they thought near.' The Mano Negra was the means used by certain anarchist elements in the South to continue their political activities while the IWMA was banished.

In 1883 the discovery of this Andalusian secret society's "crimes" prompted accusations from right-wing and left-wing political parties against its sanguinary methods. Yet, to consider them as mere common criminal acts is to ignore the historical background which led up to them. Neither the calls for the destruction of private property and terrorism against the landowners nor the strict punishment of traitors and stool pigeons were strange to the character of previous agrarian

Congrès international Socialiste-révolutionnaire tenu à Londres du 14 au 20 juillet 1881", in: Le Révolté, August 6, p. 3. See below, p. 335, notes 1 and following.

${ }^{1}$ By 1873, the Spanish Regional Federation was already thinking of organizing secretly in case it should be outlawed. In the "Correspondencia de la Comision Federal", available at the Biblioteca Arús, in Barcelona, there is a copy of a letter sent by Francisco Tomás to the Sanlúcar Federation: "if you are not allowed to meet publicly, have secret meetings. To this effect, it is advisable to assemble and organize in groups of ten members who can meet anywhere, even right in the face of the bourgeoisie." (Sept. 23, 1873) There are similar letters, addressed to other Andalusian Federations. The Circular letter No 38 of January 12, 1874, in which the Spanish Federation announced the Government decision to suppress it, recommends in its third proposition: "the local Federations which cannot meet openly will turn their public organization into a secret one..." (reproduced by Max Nettlau, Documentos inéditos sobre la Internacional y la Alianza en España, La Protesta, Buenos Aires, 1930, pp. 203-05). In the first Catalonian "conferencia comarcal" of 1875 , new Statutes are voted for the Spanish Federation because: "Since the IWMA has been banished by the Spanish Government, the Regional members have no other possibility but to organize it as a secret revolutionary society in order to assure its original goal, that is to say, the complete liberation of the proletariat." (quoted by A. Lorenzo, op. cit., pp. 342-43) A striking coincidence in thought and language may be noted between this paragraph and the opening one of the Statutes of the MN (cf. Appendix). 
underground movements and radical republican secret societies. ${ }^{1}$ The violent language of the Mano Negra was not too different from that used at times by the IWMA in Spain $;^{2}$ this violent language was so widespread that even the federalist republicans were often accused of using it. In $1872 L a$ Legalidad accused the republican newspaper La Voz de Alerta, at Cádiz, of inciting "social revolution and the liquidation of public men in Jerez and throughout Andalusia". ${ }^{3}$ A month later the same moderate newspaper reported that in the Puerto de Santa Maria, "republicans are threatening both the properties and lives of the moderates".4

The tensions between rich and poor had also been mounting in the South long before 1883; acts of protest and violence against landowners and their supporters were commonplace in the history of agrarian unrest. $^{5}$ For years before the conflict broke out in 1883 , the property of the Andalusian oligarchy provided an ideal target for peasants who were either isolated or organized into groups. The felling of trees, burning of crops, destruction of olive groves and vineyards, kidnapping and even murder were everyday terrorist acts. ${ }^{6} \mathrm{Le}$ Révolté reports in 1880 that "la petite guerre continue dans [...] la province de Xérès, les paysans continuent à incendier les maisons et les champs de leurs propriétaires, en s'acharnant surtout contre les plus rapaces; les incendies se font sur un plan bien organise."7 The tactics were not only to destroy property, hereby hurting the owners in their weakest spot

' In a pamphlet reprinted in Mallorca, in 1814 , and seized by the Inquisition at the time, we find, mutatis mutandis, similar concepts: "I swear to persecute to death, as intolerable foes of humanity, all those who oppose us be it by deed, word or in writing; I swear to equally persecute, but with the utmost rigor, that perverse being who once having joined us, tries to desert our sacred ideals (an act which is not to be expected to occur). I will never rest until I see the sacrifice of this perfidious and execrable being consummated..." (Constitucion fundamental de los libertadores del género humano).

2 In the resolutions of the "conferencias comarcales" of July, 1876, the following was agreed on: "The most perfect secrecy must be observed on the existence of the organization and its agreed line of conduct; informers must be punished as severely as acts of cowardice in the face of the enemy; all traitors to the cause of Social Revolution will be punished", A. Lorenzo, op. cit., p. 345.

3 La Legalidad, Cádiz, June 4, 1872.

4 Ibid., July 30, 1872.

- Cf. above, p. 323, note 2 .

- El Porvenir, Sevilla, Feb. 28, 1883. The Nation (N.Y., April 5, 1883) reported that: "The province [of Jerez] appears to have been honeycombed with secret societies acting under a central head, and executing its orders with blind obedience. These orders involved every variety of crime, such as murder, assault, house-burning, the destruction of vineyards and the mutilation of cattle."

7 Le Révolté, Geneva, July 10, 1880. 
- their economic position - but also to attack their most traditional and faithful allies: the Church and the armed forces. In August, 1872, a mob in the village of Rota endangered the security of the Civil Guard when its headquarters were attacked and set fire to. ${ }^{1}$ In June of the same year more than two hundred people in Jerez de la Frontera rose in rebellion and ransacked, among others, the priest's house, fired on the Pope's picture and shot down the sacred images. ${ }^{2}$ Similar events took place in Sevilla and other parts of Andalusia. ${ }^{3}$

\section{III}

After the suppression and consequent going underground of the Spanish Regional Federation it became more difficult for the government to blame sporadic outbursts of violence on any specific group. ${ }^{4}$ Yet, it is not hard to see in the Mano Negra's program a direct influence of the language used by the International itself during the years of clandestinity. In 1872, when the government threatened to suppress the IWMA, the Regional Federation declared before the opening of their Congress at Zaragoza that, should its existence be menaced, it would "solemnly [declare] the civil war, the war between classes, the war between rich and poor". ${ }^{5}$

Having been outlawed, the IWMA continued its political activities underground, grouping its scattered followers into small, local sections, with Barcelona, Madrid and the South retaining the greatest bulk of membership. As early as June, 1874, the internationalists announced at their secret congress in Madrid that 349 sections were clandestinely organized and that new ones were being regrouped all over the country, despite police persecution. ${ }^{6}$ In the next seven years the Spanish Regional Federation continued meeting at secret regional conferences ("conferencias comarcales") which substituted the larger national congresses, and anarchist delegates attended such international meetings as

${ }^{1}$ La Legalidad, August 10, 1872.

2 Ibid., June 26, 1872.

3 La Andalucia, June 22, 1872.

- However, the fact that the Regulations and Statutes were already known by 1879 , indicates that the Spanish authorities may have been aware of the political bases for most outbreaks of trouble. This emerges clearly from the letter signed by García Ceruncio (cf. Appendix).

- From the Diario de Madrid, quoted by La Andalucía, March 26, 1872.

- For more data see: Lorenzo, op cit., p. 329. A thorough study of these years is still missing. Succinct treatment can be found in José Termes Ardévol's, El movimiento obrero en España. La Primera Internacional (1864-1881), Barcelona, 1965, Ch. IV, and my Orígenes del anarquismo español (1868-1884), Doctoral dissertation, Princeton University, 1968, Ch. VI. 
Brussels (Sept., 1874), Berne (Oct., 1876), Verviers (Sept., 1877), Ghent (Sept., 1877) and London (July, 1881). ${ }^{1}$

Outspoken working-class newspapers were banned together with the IWMA, and the few which survived denied any link with the International. They abandoned their militant character and transformed into apolitical organs of information, ${ }^{2}$ until they died out or survived to adhere to the new Federation of Workers of the Spanish Region, in 1881. Yet, the clandestine nuclei which advocated the violent overturn of the government as the only means to ignite the Social Revolution, developed an ample, even though ephemeral, underground press. ${ }^{3}$ It is difficult to ascertain the efficacy of this enterprise and its precise gains, since the documentation at hand is scarce. However, the fact that more than half-a-dozen newspaper titles are known to us a century later allows us to suppose that perhaps others may have seen the light between 1874 and 1881. These publications served to coalesce the scattered sections and to keep the principles of the movement alive; such is the case of the Municipio Libre (which issued at least eleven numbers, until August, 1880) and ElOrden, Hoja socialista de propaganda $y$ de acción revolucionaria, with sixty-five numbers and several "supplements", perhaps the most widespread and widely-read revolutionary literature. ${ }^{4}$

An indication of the violent tone of these publications is provided in

1 It is suprising to see that even today many historians ignore the fact that Spain sent at least two delegates to this Congress; one from the "Unión de los obreros de la construcción", Barcelona, and the other representing the Spanish Regional Federation, which although clandestine in character, was active reorganizing itself (cf. the "Compte-Rendu du Congrès International", in: Le Révolté, July 23,1881). Giralt, Balcells and Termes, in their recent "Chronology" of social movements in Catalonia, Valencia and the Balearic islands affirm: "1881, July: No Spanish delegates were present at this anarchist Congress of the IWMA in London" (Barcelona, 1967, p. 75).

2 Such was the case of La Revista Social. Between August 13, 1873 and February 6, 1874 it appeared as "Órgano de las Federaciones Manufactureras de la Región Española"; this subtitle disappeared when the IWMA was banned. The Revista itself ceased publication only to reappear on May 15, 1874 under the same name but without any subtitle. Although its format remained the same its character was different. It stopped publishing any news directly related to Spanish politics, except when it favored the government (as in the case of the end of the second Carlist War, in March, 1876). Occasionally events abroad were also reported but it wasn't until the IWMA resumed its public activities that it resumed its role as an important organ of the anarchist press.

${ }^{3}$ Lorenzo, op. cit., p. 343, recalled the atmosphere of violence and rebellion during those years, among internationalists.

4 Other titles are: Las Represalias (Madrid, 1874), La Solidaridad (Barcelona, 1874-76), A los obreros. Saldrá cuando las circunstancias lo exijan (1875), La Revolución Popular (España, 1877), La Bandera Social (1878). 
the single-page sheet, $A$ los trabajadores, which stated that "the struggle from now on will be between rich and poor, that is to say, between working men and the idle rich, rather than between monarchists and republicans [...]". ${ }^{1}$ Another brochure without any date or clue to its place of publication, but which Max Nettlau believes to have been published between 1877 to $1879,{ }^{2}$ gives very significant practical instructions on how to launch a war on the bourgeoisie. The language is in many respects similar to that of the Mano Negra, as is the spirit that inspires both documents:

\section{"General Instructions:}

To speed up as much as possible the disorganization of the army.

To get rid of all men whose moral influence on the proletariat may imply a future danger, and after destroying all public documents, to demand the surrender of the titles of personal property. Among those documents which must be destroyed, the archives of the public notaries must not be forgotten. All those documents which represent a means of survival of the existing social order and all those people who own the ministries and businesses, must be absolutely destroyed...

Let the motto of the Revolution be: 'DOWN WITH THE EXPLOITATION OF MAN BY MAN. HE WHO WANTS TO EAT MUST WORK'.

A call to arms for insurrection must be made to all European countries. [...]

The materials for the new social structure can only be obtained by the complete destruction of the present one. In order to undertake the work of the revolution, we must keep our eyes fixed on the former society, until the working man's thirst for destruction has been quenched. Woe to him who, loving the

${ }^{1}$ Cf. the clandestine A los trabajadores, Numbers 1 to 3, Feb. 27 and 28, 1875, signed by "Varios trabajadores".

2 This document is reproduced in Spanish by Max Nettlau in his work on the International in Spain, the manuscript of which belongs to the Internationaal Instituut voor Sociale Geschiedenis, Amsterdam; it has just been edited by Renée Lamberet under the title La Première Internationale en Espagne (1868-1888), Dordrecht 1969. I would like to thank Maria Hunink, librarian, and Rudolf de Jong, head of the Spanish section at the Instituut, for their generous help and their kindness in allowing me to consult this invaluable and encyclopedic work and for permitting me to quote from it. To Renée Lamberet my gratitude for calling my attention to the importance of this book. Nettlau describes this document as: one page, in quarto, printed on two columns; he is not sure about the date but believes it to be possibly between 1877 and 1879 because it was found among others from that two-year period. 
revolution, brings to it as its first task the idea of building." 1

Another document which illustrates the same point is a Circular a los trabajadores del campo, issued by the Spanish Federation in May, 1879, in which it seems to refer to previous outbursts of protest in almost all the main towns of Andalusia. Although the IWMA denied having taken an active part in them, it criticized the "compañeros" for not having gone further in the action:

"...we find ourselves under the obligation of addressing ourselves to you so that you will know you have done little, and that you have every reason to do much more [...] You do well in demanding 'Bread or work!' But that is too little.

You must do more.

All that the granaries hold is yours. It is the sweat of your brow.

Since it is yours, you should not ask for it; you should take it. If the idling drones of the social beehive are opposed... the bees have taught you what you should do with them. [...]

We say this unto you, in case you have not come to realize this. Judge for yourselves what is better: to die a slow, contemptible and cowardly death watching your children die of want, or to die proudly taking what is yours and with the immense satisfaction of having accomplished your duty in ending so many injustices?

There is no choice. To die of starvation or to die by a bullet, it's all dying.

Let us die then like men who know their rights and want to fulfill their duty. [...]

War, collective or individual, always war, fight until they see the light, or until we have conquered.

The first ones will succumb. It is true. They will have set the example. They will have sown the true cause of the people with their generous blood.

Without the need of banners they will have stamped their goals high; so high that the concupiscent and obstinate bourgeoisie will be terrified to read in each and every one of our actions the sacred mottos:

HE WHO WISHES TO EAT MUST WORK!

THOSE WHO DO NOT WORK AND FOR ANY REASON LIVE OFF THE PEOPLE, STEAL FROM THE WORKERS! THEY ARE THE THIEVES!

1 Nettlau, manuscript, pp. 138a-138b; Lamberet, op. cit., pp. 299-300 gives a French translation. 
LET THE IDLING DRONES DIE!

THE LAND FOR THE FARMER! THE FACTORY FOR THE WORKER! THE WORKSHOP FOR THE ARTISAN! LONG LIVE SOCIAL REVOLUTION!"1

In the Regional Conferences of 1880 , the Resolutions adopted by the delegates of the different areas also showed a revolutionary spirit in agreement with the Regulations and Statutes. Point 14 of these Resolutions - entitled "On the advantages of carrying out reprisals against members of the bourgeoisie, and their possessions"2 - shows a striking similarity with the notions of the Mano Negra (cf. Article 1 of the Regulations and articles 2 and 7 of the Statutes). It should not surprise us to see that this resolution was approved by the majority of the delegations and unanimously accepted by the Andalusian regional representatives.

\section{IV}

This radical attitude of the Southern sections points to a key element in the difference between rural anarchism and the workers' movement in the urban and industrial sectors of Madrid and Barcelona. In the cities, working class solidarity relied heavily on a powerful weapon to support economic and labor claims: the strike. In the countryside different methods had to be employed; a successful strike would

1 "Circular", 2 pp., in 2 columns, quarto, no place of publication, May, 1879, reproduced in Nettlau, manuscript, pp. 142a-142c; cf. Lamberet, pp. 311-314. 2 From the "folletín" of Tierra y Libertad, May, 1916, quoted by Díaz del Moral, op. cit., Ch. VI, p. 118. Both the language and goals of the MN are very similar to those of contemporary radical movements in other European agrarian countries. In Ireland, between 1879 and 1883, there was a state of violence and discontent among the rural workers; organizations like the Fenians, the Agrarian League, the secret society of the Invincibles, among others, were fighting the government and the landed aristocracy through acts of violence and terrorism very similar to those employed in Andalusia. The Revista Social and Le Révolté give very detailed accounts of these events, as well as of Russian nihilism and terrorism. Both of these newspapers stressed the significance of these acts and the importance they may have had in Spain (cf. Le Révolté, Sept. 4 and Oct. 17, 1880 and Revista Social, Oct. 13, 1881). Long before these developments occurred, Bakunin and Nechaev's Revolutionary Catechism (1869) preached violence and terror just like the Mano Negra years later: "We recognize no other activity but the work of extermination, but we admit that the forms in which this activity will show itself will be extremely varied - poison, the knife, the rope, etc. In this struggle revolution sanctifies everything alike" (quoted by $\mathrm{E}$. H. Carr, Michael Bakunin, N.Y., 1961, p. 395). Although we have not been able to establish when the Catechism became known in Spain, it may be interesting to bear in mind these curious similarities. 
hardly have been possible given the enormous surplus of unemployed and needy "jornaleros" who would readily have taken the place of their comrades. ${ }^{1}$ Only in the more specialized agricultural industries (like the wine industry) was the strike possible, but its results affected only a minority of the active southern population. Also, the lack of an all-encompassing agrarian workers' union made any kind of political organization more difficult. Because of this specific situation and the impossibility of coordinating a vast political movement in such an extensive area, any organization called for small cells which, although scattered, based their cohesion on very strict disciplinary rules and severe punishments for anyone who broke them.

It was these circumstances that made the Andalusian Federations reject the strike and, instead, turn towards sabotage and destruction as a means of checkmating the economic power of the landowner, as well as undermining private property. As far as we know, this strategy was never debated in any of the leading congresses of the Spanish Federation in the years between the first one, Barcelona, 1870, and the last national congress of Madrid, 1874. In the South, the question of organization became crucial after 1875 when the regional conferences replaced the national caucuses and the break-down of a coherent nationwide association led to an increase in regional autonomy and initiatives. $^{2}$

The different goals of the local federations of the South and the Federal Commission in Barcelona inevitably clashed. No voices of sympathy for the peasants' struggle were heard in the leading spheres of the Regional Federation, and the leaders in Catalonia regarded the Andalusian rural workers as a mass of exploited and illiterate peasants, incapable of organization. ${ }^{3}$ It is no surprise, then, to learn that these Southern activists felt betrayed by their urban leaders. One of the members of the Regional Federation at Barcelona, Eudaldo Canibell, recalls that in one of their meetings the Mano Negra sentenced the Federal Commission to death: “...there suddenly sprang up a group called Mano Negra, in Jerez de la Frontera, formed by fanatical (or unbalanced) federate anarchists, who sentenced us to death for opposing their ideas and nonsensical plans, which we refused to support". 4

1 Cf. Revista Social, June 30 and July 21, 1881.

Cf. Lorenzo, op. cit., Part II, Chapters 8-9, pp. 339-381.

Ibid., p. 409 and passim.

- Eudaldo Canibell's unpublished memoirs, mentioned by M. Nettlau, manuscript, pp. 195-196; cf. Lamberet, p. 430. It is worth noting that Nettlau, following the official line of the IWMA, denies the validity of this evidence, saying that Canibell must undoubtedly have been mistaken in talking of the MN instead of the Desheredados! 
The disenchantment of the rural masses with the traditional leadership and organization of the Spanish IWMA during the years which followed the Revolution of 1868 led the more determined groups to break away from the tactics of legal coexistence of the urban anarchists. The years of secrecy were the right moment for their organization to take the path of militant and activist radicalism. It is no surprise to find out that as the Mano Negra was acting in Jerez, other secret societies were emerging in different areas of the South. In Cádiz, a revolutionary group known as Los Desheredados appeared at about the same time. ${ }^{1}$ In 1883 the Crónica de los Trabajadores reports that it had received "two leaflets stamped with a seal which reads: Los Desheredados. Organización revolucionaria anarquista. Comité de guerra de la nación española. In the background of this seal, a dagger and a torch are engraved in the form of a cross". ${ }^{2}$ As late as 1884 this group was still using language similar to that of the Mano Negra: "the bourgeoisie cannot be considered as human beings, and have forfeited the rights of man". ${ }^{3}$ Other secret societies were also discovered at the time of the Crimes; a clandestine group of anarchistic character "brutally nihilistic in its plans" was denounced in Marchena. "Several others were discovered in Málaga. One of them was described as "an agrarian society with characteristics similar to the Mano Negra but less defined, probably formed by members of both sexes who broke away from it". 5

\section{V}

The differences within the anarchist movement were not only tactical ones between agrarian terrorism and syndical organization, but ideological ones between the principles of collectivism, as defended by the Federal Commission, and those of anarchist communism, increasingly popular among anarchist groups in the South. Although the Regional Federation of Spanish Workers remained faithful to Bakunin's collectivism, libertarian communism had started to become the official doctrine of other European Federations, at least from the time of the

1 The Desheredados held a clandestine congress in Cádiz, in 1884. In the pamphlet published with the Manifesto and Statutes, in December, 1884, it was stated that this was the third congress and the sixteenth year of the organization; thus, the first must have been as early as 1868 - the year when anarchism entered the Peninsula.

${ }^{2}$ Crónica, No 3, Feb., 1883, p. 25.

${ }^{3}$ Manifiesto del Tercer Congreso, Dec., 1884; cf. Appendix, opening statements of Regulations.

4 El Posibilista, Sevilla, quoted by El Guadalete, March 6, 1883.

s La Andalucía, March 1 and 3, 1883. 
London Congress of 1881. At this meeting it was decided to support a motion in favor of propagating the communist ideals among the peasants. ${ }^{1}$ Furthermore, it was decided to explain to rural workers the need for "l'expropriation de tous ceux qui ne cultivent pas la terre eux-mêmes, et la mise de ces terres en commun, à la disposition des communes". This resolution was strongly defended by most delegations including the two from Spain. ${ }^{2}$ The year before, Carlo Cafiero had given a speech to the Jura Federation in which he defended the anarchocommunist idea: "Nous voulons la liberté, c'est á dire, l'Anarchie et l'Egalité, c'est à dire, le Communisme."3

Communist notions were not strange to rural Southern Spain where the basic theoretical principles of ownership of the land and the working tools by the commune plus the distribution of all goods produced according to one's needs, were tactically implemented by extreme revolutionary acts of terrorism and propaganda by deed. ${ }^{4}$ These ideas had awakened some echoes by 1882, and at the Congress of Sevilla of that year, communists and collectivists quarrelled openly for the first time. Miguel Rubio, delegate from Montejaque (Sevilla) opposed José Llunas (Barcelona), and defended communism as the only truly anarchist doctrine. ${ }^{5}$ In the ensuing years, this division

1 Cf. "Compte-Rendu du Congrès International", in: Le Révolté, July 23, 1881, p. 3. This resolution is similar to the one approved a year before at the meeting held by the Federation of the Jura at Chaux de Fonds, on October 9-10, 1880. There it was decided that "le Congrès recommende à l'attention spéciale des sections ce genre de propagande [révolutionnaire] et décide d'entreprendre la publication d'imprimés destinés à propager les idées du socialisme révolutionnaire parmi les agriculteurs..." (5th resolution), Le Révolté, Oct. 17, 1880. In London, a delegate from this newspaper revealed that their anarcho-communist pamphlets of propaganda "s'écoulent à un très grand nombre d'exemplaires, dans tous les pays" (ibid., July 23, 1881, p. 3).

2 Cf. "Compte-Rendu du Congrès...", in: Le Révolté, August 20, 1881, p. 3.

${ }^{3}$ Le Révolté reproduces the whole speech under the title "Anarchie et Communisme", November 13 and 27, 1880, pp. 1-2.

" "Propaganda by deed" had become associated with communism at least since the Congress of London when it was officially accepted as a tactical aid to communist proselytizing. Yet, one must keep in mind that "direct action" was practised long before 1881 . These tactics were initially defended by the Italian Federation as early as 1873 (cf. George Woodcock, Anarchism, N.Y., 1962, p. 337). Such leaders as Errico Malatesta, Carlo Cafiero, Andrea Costa became the disseminators of the new tactics; by the late seventies the activist ideas had spread over most European countries.

5 See Federico Urales, La evolución de la filosofía en España, La Revista Blanca, Barcelona, 1934, Vol. II, pp. 160-161, and Lorenzo, op. cit., p. 431. A complete study on the differences between collectivism and anarcho-communism has still to appear, but for a partial discussion of this question in Spain see Urales, op. cit., pp. 160-190, and José Cascales y Muñoz, El apostolado moderno, Barcelona-Madrid, n.d., pp. 189-223. 
sparked off harsh attacks from the collectivist Revista Social (Sans) against the Federal Commission and certain press organs like Bandera Social (Madrid), Federación Igualadina (Igualada), La Autonomía (Cádiz), which were asking for a doctrinal revision and discussion of the movement. ${ }^{1}$ The collectivists accused them of acting in a fashion which helped "perturbadores" such as Los Desheredados and other dissident minority groups which had been leaning towards communist anarchism since the Congresses of Valencia (1882) and Sevilla (1883). ${ }^{2}$

The Mano Negra is a typical example of one of those minority groups which disagreed and did not follow the official line set by the Spanish Federations. Although an ideological estrangement is not clearly stated in the document we are publishing, the fact that the IWMA rejected this clandestine group and the menacing replies with which the Mano Negra answered provide sufficient ground for stating quite definitely that a profound division existed within the movement, not only in terms of tactical activities, by also of serious ideological differences. Although the Mano Negra was probably finally crushed in 1883 , its basic ideals did not disappear. They were carried on by other Andalusian organizations, such as Los Desheredados, who continued the fight, and by 1886 communist anarchism began to be officially adopted by some working-class newspapers. ${ }^{3}$

${ }^{1}$ Cf. Revista Social, Sans, 2a época, March 26, p. 2 ; April 9, p. 2 ; April 23, p. 2; May 14, 1885, p. 1. The Revista Social (March 26, 1885, p. 1) also has a reply to an article published by the Revue Anarchiste Internationale (Bordeaux) in March 20, 1885, pp. 81-82. The French journal asserts that communist anarchism was very strong in certain areas of Spain and that "le communisme-anarchiste implanté en Espagne y créera bientôt une agitation et un mouvement dont les résultats ne seront pas longs à se faire attendre. Il n'est pas d'ailleurs de contrée qui se prête mieux que l'Espagne à l'action individuelle, à la propagande par le fait." In its issue of April 2, 1885, the Revista Social devotes a long front page attack to Le Révolté and the communist anarchists, which ends with the call: "Collectivists defend yourselves!"

2 See Revista Social, April 23, pp. 1-2; April 30, pp. 1-2 and May 14, 1885, pp. 1-2. Le Ça Ira published in August, 1888, an excellent brief note on the situation of the Spanish labor movement at the time and mentions the rupture between both factions after the Mano Negra trials.

3 The first anarcho-communist newspaper that we know of in Spain is La Justicia Humana, which appeared in Barcelona in 1886. In Catalonia propaganda by deed became a form of action supported by dissenting elements which were closely connected with similar groups in other European countries. In the subsequent years such publications spread throughout the whole Peninsula: Tierra y Libertad (1888); La Revolución Social (1889); El Primer Anarquista, El Revolucionario, El Socialismo (1891); La Tribuna Libre (1891-1892); La Conquista del Pan, El Oprimido, La Revancha, El Rebelde (1893); El Comunista, El Eco del Rebelde (1895); Ariete Comunista (1896), among many others. 
The significance of the Mano Negra in the history of early Spanish anarchism is manifold. The merciless persecutions by the government and the breach within the International itself led to the gradual disintegration of the IWMA. In a few years the powerful Revista Social, which in 1882 was printing and distributing 20,000 copies, languished and finally disappeared in 1885 . The few surviving newspapers engaged in bitter disputes over collectivism and communism. By 1888 the Federation was officially dissolved, thus bringing to an end the first stage of the Spanish labor movement.

Despite its disruptive consequences, the Mano Negra was the most suitable kind of organization the revolutionary Andalusians could find for their needs and situation. It was perhaps conceived in more primitive terms than what the urban anarchist groups would have desired and, in the long run, proved less effective since it was destroyed. Yet, such agrarian secret societies became the melting pot for the tactics of traditional secret organizations and radical anarchist ideology. They are an example of how certain rural areas in Spain endeavored to organize and fight for social and economic change, combining tradition and conspiracy with modernity and socialism.

\section{APPENDIX ${ }^{1}$}

Archivo General de Palacio

Secretaría de su Majestad - Legajo 10.077

La Mano Negra. Reglamento de la Sociedad de Pobres, contra sus ladrones $y$ verdugos, Andalucia.

Dirección General de la Guardia Civil - Secretaría:

Excmo. Sr.:

El Coronel Subinspector del $4^{\circ}$ tercio del Cuerpo de mi cargo, en oficio reservado de fecha 5 del actual, me dice lo siguiente:

"Excmo. = Siendo este país de los en que al parecer con más prosélitos cuenta la Internacional, ha sido lo que me ha impulsado en el curso de mis continuas salidas y en especial las verificadas en este año con motivo de las huelgas intentadas, y revista anual, a fijar mi atención sobre dicha Sociedad, procurando adquirir datos sobre su origen, organización y compromisos socialistas que tengan adquiridos sus afiliados.

Conociendo la índole de los habitantes del país, no creo, ni espero, que pueda alterarse el orden público; pero no por eso hemos de dejar de convenir en que realmente existe organizada dicha Sociedad

1 The spelling in the Spanish text has been modernized. 
socialista dentro de las provincias que constituyen el tercio de mi mando, desde hace mucho tiempo, y que se halla subdividida por agrupaciones o núcleos, que pudieran muy bien aprovecharse, para sus miras y fines, de la miseria que en la actualidad aflige a la mayoría de los braceros de este país.

Constantemente y con la mayor vigilancia me ocupo de ella, máxime por si algún día pudiera tener relación o connivencia con lo que acaeciendo está en la vecina república de Francia. Creo oportuno y conveniente poner en el superior conocimiento de V.E. que en carpeta reservada conservo relaciones nominales de los principales agentes instigadores de diferentes localidades, para poder en su día darles el golpe de gracia merecido si nos lo permite el Código y presentan bien las circunstancias.

Por la adjunta copia del Reglamento especial, titulado La Mano Negra porque se rigen los socialistas de esta región. Comprenderá V. E. su organización, y que el lenguaje usado en él es el mismo que nos transmite la prensa periódica de lo que está sucediendo en Francia, temible en todos conceptos para la gente sensata, produciendo constantes alarmas indebidas. Tengo la honra de ponerlo en el superior conocimiento de V.E. para los fines que estime convenientes."

Y lo traslado a V.E. para su conocimiento y efectos oportunos, con inclusión de un ejemplar del Reglamento de que se hace mérito. Dios guarde a V.E. muchos años.

Madrid, 9 de noviembre de 1882.

Excmo. Sr.:

Tomás García Cerunio (Rubricado)

Al pie- Excmo. Sr. Ministro de la Guerra

REGLAMENTO

Considerando que todo cuanto existe y aprovecha para el bienestar y goces de los hombres ha sido creado por la fecunda actividad de los trabajadores:

Que por efecto de la absurda y criminal organización de la sociedad presente, los trabajadores lo producen todo, y los ricos holgazanes se lo quedan entre sus uñas:

Que por esa causa, ellos se aseguran el imperio eterno sobre los pobres, dentro de cualquier forma de gobierno que sea:

Que debido a esto, todos los partidos políticos tiemblan ante la idea de que pueden ser atacados en su base las instituciones que tales monstruosidades defienden:

Que no será fácil atacar vigorosamente, como es necesario, a ese 
gran mal, mientras no se destierren de los nobles pechos de los rudos cuanto leales trabajadores, las falsas ideas de respeto a la propiedad, y de perdón a las ofensas:

Que la propiedad adquirida por la explotación del trabajo ajeno, aunque sea adquirida por la renta o el interés, es de las que deben considerarse como mal adquiridas, por no haber otra legitima que la obtenida absolutamente por el trabajo productivo, y como tal directo, personal y útil:

Por estas razones, y en vista de que todas las leyes están hechas en provecho de sus privilegios y en contra de nuestros derechos,

Declaramos a los ricos fuera del derecho de gentes, y declaramos que para combatirlos como se merecen y es necesario, aceptamos todos los medios que mejor conduzcan al fin, incluso el hierro, el fuego y aun la calumnia.

Declaramos querer ser los vengadores de nuestros hermanos, y para este objeto, y aclarar el día de la gran revolución popular, se fundó en España esta asociación que trabajará de acuerdo con las del mismo carácter y tendencias de todos los países.

Artículo $1^{0}$ : la existencia de esta asociación será eminentemente secreta. El individuo que, bien sea por debilidad, ligereza, exceso de confianza, o mala fe, revele alguna cosa referente a la misma, o que pueda dar a comprender que pertenece a ella, recibirá inmediatamente el castigo correspondiente, que podrá ser suspensión temporal por tiempo limitado, o muerte violenta, según se estime la gravedad del caso o de la revelación.

Artículo $2^{0}$ : El cumplimiento de los deberes y la ejecución de los trabajos que a cada uno de sus miembros se le confíen, será obligatorio, sin ningún género de excusa, a excepción del que se halle imposibilitado en la cama por falta de salud, y en este caso remitirá por conducto de su proponente $\mathrm{y}$ por escrito, la causa de su imposibilidad, acompañando de las señas de su domicilio a la Mano Negra, que eśta acudirá inmediatamente en su auxilio y ayuda.

Al tratar de evadirse del cumplimiento de alguno de los deberes que se le confíen, por algún otro objeto, será considerado como traidor.

Artículo $3^{0}$ : Todos los miembros de esta asociación están obligados a ocultar sus simpatías por ellos, quedando su buen nombre y la reputación que habrá de adquirir, confiados a los actos que ha de realizar.

Artículo $4^{0}$ : Los que pertenezcan a esta asociación deberán ser constantes en su profesión $\mathrm{u}$ oficio respectivo, $\mathrm{y}$ procurarán hacer entender a toda su familia y amigos, que han adquirido la costumbre de economizar, a fin de que no pueda extrañar nadie que tenga recursos de qué vivir, cuando por servicios prestados a la asociación u otra razón tenga que abandonar su trabajo. 
Artículo 50: Todos los miembros de esta asociación recibirán un subsidio cuando presten a ella servicios, en relación con ellos; pero ninguno podrá decir, bajo ningún pretexto, la cantidad que reciba. El que falte a este como a cualquiera otro de los deberes, será severamente castigado.

Artículo $6^{0}$ : Para formar parte de esta asociación, deberá adquirir este derecho por medio de un servicio que ha de prestar, y el cual le será indicado por la persona encargada de presentarlo.

Artículo $7^{\circ}$ : Cuando algún asociado crea hasta encontrar entre sus amigos alguno que juzgue a propósito para formar parte de la asociación, lo hará presente a la misma por el conducto indicado en el artículo $2^{\circ}$, sin decirle a él una palabra, y en ella se acordará la manera de iniciarlo.

Artículo $8^{\circ}$ : Todos los miembros de esta asociación deberán tener siempre presente, que forman una grande y formidable máquina de guerra, de la cual cada uno representa una pieza; por lo cual deben aceptar el deber de funcionar, dentro de su esfera, al compás que lo haga necesario el movimiento de todo el mecanismo.

Artículo 90: El que dejare de cumplir con su deber en el crítico momento en que estén cumpliendo todos o parte de sus compañeros, será considerado como traidor, y pagará instantáneamente con la vida su grave falta.

\section{ADMISIÓN DE ASOCIADOS}

Artículo $1^{\circ}$ : Ningún individuo podrá ser admitido sin haber obtenido de su parte las pruebas irrecusables de su voluntaria adhesión.

Artículo $2^{0}$ : Cuando haya cumplido el nuevo candidato la misión que se le haya confiado, podrá ser presentado al grupo que deba admitirlo, para lo cual deberán adoptarse todas las precauciones que se consideren más conducentes al objeto de que no pueda saber donde fue recibido.

Artículo 30: Los que compongan el grupo citado se presentarán cuidadosamente dispersados.

Artículo $4^{0}$ : En aquella sesión, el que presida el acto, hará a los allí presentes una relación de las cualidades que se le imponen al nuevo candidato, y después de relatar la misión que le fue confiada, le invitará a que explique la manera como la llevó a cabo, haciéndole sobre este punto todas las preguntas que crea necesarias para conocer si aprecia la importancia de lo que hizo, y si al llevarla a cabo procedió con el tacto y resolución necesarios.

Artículo $5^{\mathbf{0}}$ : Si alguno de los miembros presentes quisiere dirigirle alguna pregunta, podrá hacerlo por conducto del presidente. 
Artículo $6^{\circ}$ : Esto hecho, se dará el acto por terminado, retirándole del lugar de la reunión con las mismas precauciones con que fue llevado.

Después se discutirá sobre su admisión, y si fuere acordada por unanimidad, podrá invitársele desde el siguiente día.

Artículo $7^{\circ}$ : Si resultase un solo voto en contra, no podrá ser admitido hasta que éste manifieste haber cambiado de opinión.

\section{ESTATUTOS}

Habiendo sido la Asociación Internacional de los Trabajadores puesta fuera de la ley por los gobiernos burgueses, imposibilitándola por este motivo para resolver pacíficamente la cuestión social, y de cuya resolución no puede prescindir, ha tenido que convertirse en organización revolucionaria secreta, para llevar a cabo la revolución social violenta; pero como para llegar a este último tienen que pasar algunos años, y la burguesía no para de cometer crímenes contra la clase trabajadora, cuyos crimenes es menester castigar antes que llegue la revolución social; y considerando que todos los federados no son a propósito para llevar a cabo estos castigos de un modo conveniente, por estas razones se forma un núcleo denominado Tribunal Popular, cuyo tribunal será el encargado de sentenciar y castigar los crímenes de la burguesía. Este tribunal se regirá por los siguientes estatutos:

Art. $1^{0}$ : Se forma un Núcleo de diez individuos que pertenezcan a la asociación internacional de los trabajadores y se juzguen capaces para este objeto.

Art. $2^{0}$ : Castigará los crímenes de los burgueses y sus dependientes por todos los medios que sean posibles, bien sea por el fuego, el hierro, el veneno, o de otro modo.

Art. $3^{0}$ : Este Núcleo celebrará sesión ordinaria el primero de cada mes, y extraordinaria siempre que sea necesario: en las ordinarias será válido el acuerdo, cualquiera que sea el número que se presente, y en las extraordinarias se necesita que se reúnan las dos terceras partes, y además que todos los individuos sean citados en tiempo necesario para poder hallarse en la sesión.

Art. $4^{0}$ : En las sesiones ordinarias cada uno dará cuenta del modo como llevó a cabo sus represalias; los inconvenientes o ventajas que halló en el modo de llevarla a cabo, a fin de que por este medio se vayan instruyendo todos: también se tratará de hacer las represalias que haya.

Art. 50: Cada individuo de este Núcleo inventará todos los medios de pegar fuego, de asesinar, de envenenar y, en fin, todos los medios de hacer daño, y los someterá al exámen del Núcleo.

Art. $6^{0}$ : En las sesiones extraordinarias sólo se tratará de represalias que haya que hacer. 
Los socios serán admitidos en las ordinarias.

Art. $7^{\circ}$ : Cada individuo del núeleo pagará una cuota de cinco céntimos de peseta semanales, para gastos de correspondencia; y si sobrase se empleará en lo que se determine.

Cuando se ofrezca hacermás gastos que los fondos que hubiese, se hará un repaso entre los individuos, y en casos muy apurados se pedirá a la federación.

No se harán castigos que comprometan a los individuos, sino que se deben aprovechar todas las ocasiones que se presenten favorables. Sin embargo, cuando se crea necesario comprometerse y aun exponer la vida, hay que hacerlo, y con bastante energía, usando de todas la armas.

Son casos de exponerse cuando se haya amenazado a alguno por medio de cartas antes de hacer el hecho y él toma entonces precauciones; en tal caso, para que la amenaza no queda sin efecto, es menester comprometerse.

Los daños se causan siempre en las haciendas, no habiendo proporción de causarlos en las personas.

A ningún individuo se le obligará a hacer más de lo que libremente se comprometa, y aunque rehuse hacer algún hecho por no hallarse capaz, no se le obligará; pero una vez aceptado es obligatorio y se considerará como traidor; si haciendo uso de la garantía que le concede este artículo, no acepta nunca ninguno, será considerado nulo y será expulsado.

Sobre los expulsados hay que tener una continua observación, para castigarlos con la muerte si se les prueba que han descubierto algo.

Para matar a un traidor no hay que reparar que sea amigo, hermano o padre; pues nunca pagará bastante con la vida el que quiere perder la de muchos.

Si al Núcleo de una localidad no le es posible quitarle la vida por ser todos conocidos del Núcleo, o por otro objeto, avisarán al de otra localidad para que lo hagan sin darse a conocer con él, y haciéndole alguno amigo suyo; pero para esto es preciso que reciba un aviso firmado y sellado por el Secretario y Presidente de Sección, en que se preceptuó y proveyó su muerte.

Los Secretarios tendrán nombres supuestos, que no los sabrán más que los de otros Núcleos, y siempre que se firmen con el supuesto se le reconocerá y dará conocimiento al Núcleo a que se dirija la carta. Tendrá en su poder el sello. El Presidente firmará las actas de las sesiones con las iniciales de su nombre invertidas: tal es el régimen que debe observarse.

El núcleo no se disolverá hasta que se haga la revolución social.

Los que ingresen en la Sociedad no se podrán retirar aun cuando lleguen a ser propietarios; sólo se podrán retirar cuando se muden de pueblo y 
en el que no haya Núcleo; pero si lo hay ingresarán en él mediante una credencial que llevará del que se retira o abandona.

Los beneficios que realice serán colectivos del Núcleo, y no de determinados individuos, y se les podrá dar la inversión que el Núcleo acuerde.

Es deber de los miembros proponer reformas en el reglamento, para mejorarlo, o pedir la supresión de artículos.

Los hechos que se hagan sin haber sido acordados, por el Núcleo, no es éste responsable, a menos que luego declare que los individuos han obrado bien, y apruebe el hecho.

Siempre que haya un voto en contra de algún hecho, aquel individuo no puede ser obligado, ni hacerle responsable de nada.

No se hablará de ningún hecho en las plazas ni en las calles, como no sea entre los del Núcleo, y en voz baja, y que no haya gente en cuarenta pasos lo menos.

Tampoco se hablará en el campo por detrás de vallados o tapias, para evitar espías.

Cuando se vaya a hacer un hecho, deben llevar acordada la declaración que han de dar caso de ser cogidos, lo mismo que si fueran también por sospechas. Si se cogen en el delito, también acordarán del modo como hace la $1^{\mathrm{a}}$ y en $\mathrm{T}$.

Cuando se le proporcione alguno sólo hacer al $g^{0} \mathrm{~d}^{\mathrm{a}}$ podrán $\mathrm{h}^{\mathbf{a}} \sin$ riesgo. ${ }^{1}$ Uno acordará la conducta de dar cuenta en la primera sesión ordinaria venidera.

El Núcleo o cualquiera individuo de él podrá valerse de otros que no pertenezcan al mismo ni a la federación, para llevar a cabo algunos hechos, pero sin darle cuenta de la organización.

En las sesiones ordinarias se presentarán enmiendas a los artículos de este reglamento, los acuerdos que tendrán lo menos dos terceras partes de los presentes.

Antes de admitir un individuo se le leerá el reglamento por tres o cuatro veces, y después se le darán tres días de término para que acepte o no.

Al ingresar, a todos se les cambiará el apellido, y se conocerán entre sí por los que se les impongan, y con ellos firmarán los documentos.

Los apellidos serán sustituídos por nombres propios de personas.

Es deber de los miembros enseñar a sus hijos, y en general a los trabajadores, el tener odio a los ricos, y a todo el que quiera dominarlos, o se quiera hacer superior y quiera vivir a costa del trabajo de los demás.

1 These abbreviations are the same in both versions of the document. We have not been able to decipher their meaning. 
Extracto interesante de una de las proclamas circuladas [ejemplo dado por el informante]:

Infames explotadores. El día de la justicia popular se acerca: temblad, infames asesinos; queréis obligarnos a sucumbir a vuestros brutales deseos por medio del hambre, y nosotros, en medio de nuestra miseria, hemos jurado venganza, y la llevarémos a cabo, tan terrible, que espante al mundo, si antes no desistís del infame método que habéis adoptado.

Esta sirve para daros aviso, pues tenemos preparada una buena dosis de petardos y aparatos de dinamita, para hacer volar todas las casas de los burgueses, si es que desobedecen nuestras órdenes.

Acordado en sesión extraordinaria por este Núcleo vengativo ejecutorio.

Pueblos en donde existe el mayor número de socialistas, según averiguaciones practicadas hasta el mes de sept. de 1882:

Jerez de la Frontera, Arcos de la Frontera, Sanlúcar de Barrameda, Ubrique, Tesorillo, Bornos, Paterna, Grazalema, Medina-Sidonia, Setenil, Alcalá del Valle, Écija, Osuna, Carmona, Marchena, Arahal, Lebrija, Cazalla de la Sierra.

\section{Observaciones:}

$1^{0}$ : Fijando la atención sobre la mayoría de los crímenes cometidos en este país, y el sinnúmero de malhechores aprehendidos por la fuerza de la Guardia Civil, fácilmente se comprende que muchos de ellos son originarios del reglamento anterior.

$2^{\mathbf{0}}$ : Véanse la mayoría de las causas incoadas y tramitadas por los respectivos juzgados de primera instancia sobre incendios, talas de montes y arbolados, heridas o asesinatos, así como las de los individuos, detenidos infraganti por dirigir anónimos pidiendo dinero, y se patentizará claramente en muchas de ellas la existencia de la Sociedad y sus Núcleos.

$3^{0}$ : La Guardia Civil vigila sin descanso para que no se cometan los desmanes $y$ hazañas de que trata el reglamento anterior; patentizándolo las muchas detenciones verificadas por dirigir anónimos pidiendo dinero, gran número de incendiarios, y otros excesos, contribuyendo con el mayor celo a la conservación individual de todas las personas y propiedades, según es público y notorio.

$4^{0}$ : Conoce asimismo a muchos socialistas en sus respectivas localidades y a algunos de los que prestan grande cooperación.

$5^{0}$ : Ha conservado y conserva un descanso en que no se alterará el 
orden público, a pesar de la precaria situación por que atraviesa el país, y contribuyendo además con su representación y fuerza moral, para que cesen algunas huelgas iniciadas en el presente año.

Es copia.

El General director

Tomás García Cerunio (Rubricado)

[TRANSLATION]

General Archive, Royal Palace, His Majesty's Secretariat, File No 10,077

The Mano Negra. Regulations of the Society of the Poor against their thieves and executioners, Andalusia.

General Office of the Civil Guard, Secretariat:

Your Excellency:

The Colonel Subinspector of the Fourth Corps under my command, has informed me in a confidential memo, dated the 5th of the current month, of the following:

"As a result of the fact that many people in this country seem to be members of the International [IWMA], and especially because of the most recent attempted strikes we have had, I was compelled to devote a great deal of attention to the International in my annual inspection, trying to gather data about the origins of this society, its organization and the socialist agreements its members have made.

My knowledge of the mood of the country leads me to believe and expect there will be no change in public order. Nonetheless, we must agree that this Socialist society has been well organized for a long time in the provinces which belong to the area under my jurisdiction. It is subdivided into groups or nuclei which could very easily take advantage of the poverty endured by the majority of the braceros in this country, and use it for its own ends and goals.

I have constantly and diligently kept my eye on it, especially since one doesn't know if it may at sometime be linked to what is happening in our neighboring country, France. I must bring to your high consideration that I keep in a reserved folder, lists of the principal agitators in the different areas, so that we may, at the proper time, deal the society the final blow, if the Law allows us and the circumstances are ripe.

The enclosed copy of the special regulations entitled the Mano Negra, which the socialists of this region follow, will enable you to understand its organization. You will also notice that its language is very similar 
to what newspapers tell us is happening in France, dreadful in every way to all sensible people, and thus constantly alarming them unduly. I am very honored to bring it to your high attention for whatever purposes you feel it may be convenient."

I enclose this for your attention, including a copy of the regulations he refers to.

May God protect Your Excellency for many years.

Madrid, November 9, 1882.

His Excellency:

Tomás García Cerunio (Rubricated)

[At the bottom:]

His Excellency, the Minister of War

\section{REGULATIONS}

Considering that all that exists for the well-being and happiness of man has been created by the productive effort of the workers:

That as a consequence of the absurd and criminal organization of the present society, workers produce everything and the idle rich keep it for themselves:

That because of this they make sure that they will always be in a position to dominate the poor whichever form of government may exist:

That because of this, every political party shivers at the idea that the very foundations of these monstruous institutions may be attacked:

That it will not be easy to attack this great evil vigorously, as is necessary, until we banish from the noble hearts of the ignorant but loyal workers all false ideas of respect for private property and of forgiveness for offenses they receive:

That the acquisition of property by the exploitation of the labor of others, although it may be obtained by rent or interest, should be considered wrong, since property which can be considered to have been legitimately acquired can only be attained by productive - and as such, direct, personal and useful - work:

For the above mentioned reasons, and also in view of the fact that all laws are made in favor of their privileges and against our rights:

We declare the rich to have forfeited the rights of man and we declare that in order to combat them as is necessary, we accept all means that will help us achieve our end, including those of knifing, burning and slander.

We also declare that we want to be the avengers of our brothers, and for this reason this association was founded in Spain, with the purpose of illuminating the day of the great popular revolution. It will work for 
this purpose in agreement with all others having the same intentions and tendencies in all other countries.

Article 1: The existence of this association is strictly secret. The individual who because of weakness, carelessness, excessive trust or bad faith reveals anything about it, or gives away the fact that he belongs to it, will immediately receive the corresponding punishment, which may be temporary suspension for a limited time, or violent death, depending on the seriousness of the case, or of the information revealed.

Article 2: No member will be excused from carrying out his assigned duties, unless he is bed-stricken because of illness, and in that case he will forward through his sponsor a written excuse, together with his address, to the Mano Negra, which will immediately help and assist him. However, anybody who avoids performing his assigned duties for any other reason than the above mentioned, will be considered a traitor.

Article 3: All those who belong to this association must conceal their friendship towards fellow members; any fame or reputation they may acquire will depend on the deeds they perform.

Article 4: All those who belong to this society must persevere at their respective trades and professions, and they will tell their family and friends that they have acquired the practice of saving, so that no one will be surprised that they have sufficient means to get by when they have to abandon their work in order to perform services for the association.

Article 5: All members will receive a subsidy for their services, but no one, under any circumstances, can disclose the amount received. Whoever fails in this or any other duty, will be severely punished.

Article 6: In order to become a part of this association one must earn the right by means of a rendered service, which will be indicated by the person in charge of introducing the new member.

Article 7: When any member believes that he has found someone among his friends whom he considers as a suitable candidate for membership of the association, he will introduce him by the means explained in Article 2, without letting the prospective member know that he is being considered for membership; the Association will then agree as to how this member is to be initiated.

Article 8: All members of this Association must always bear in mind that they are a part of a huge war machine, and therefore they must accept their duty within their sphere whenever it is necessary for the functioning of the machine as a whole.

Article 9: Anyone who fails to fulfill his duty at a crucial moment, 
when other fellow-members are fulfilling theirs, will be considered a traitor and will immediately pay for his serious offense with his life.

\section{ADMISSION OF MEMBERS}

Article 1: No individual will be admitted without first having given absolute proof that his decision to join is a completely voluntary one.

Article 2: When the new candidate has completed the mission entrusted to him, he will be presented to the group that is to admit him. All necessary precautions must be taken so that he will not know where the initiation ceremony took place.

Article 3: All those who constitute the group will take care to arrive separately.

Article 4: He who presides over that session will report to those present on the qualities of the new candidate. After giving an account of the mission he was entrusted with he will invite him to explain how he accomplished it and he will be questioned whenever it is thought necessary in order to see if he appreciates his work and if he has carried it out with the appropriate tact and resolution.

Article 5: If any one of the members present wish to question him, he may do so through the president.

Article 6: This done, the meeting will be adjourned and the new candidate will be taken from the place of the gathering with the same precautions with which he was brought.

If, after the question of his admission had been discussed, he were to be accepted by a unanimous decision, he may be invited to start the following day.

Article 7: If there is a single vote against him, he will not be admitted until the dissenting member changes his mind.

\section{STATUTES}

As the International Working Men's Association was declared illegal by the bourgeois governments, thus preventing it from peacefully solving the social problems which must be resolved without further delay, it has been forced to turn into a secret revolutionary organization in order to bring about the violent social revolution. But since it will take several years until we can achieve these aims, and the bourgeoisie still goes on perpetrating crimes against the working classes, it will be necessary to punish these crimes before the social revolution comes. Taking into consideration that not all members of the International are fit to carry out these punishments in a suitable manner we are creating a central group called the Tribunal Popular, which 
will pass sentence and punish the crimes perpetrated by the bourgeoisie. This tribunal will abide by the following statutes:

Article 1: A group of ten individual members of the International Working Men's Association who consider themselves capable of this task will be created.

Article 2: It will punish the crimes committed by the bourgeoisie and its subordinates by all possible means, even if it means resorting to burning, knifing, poisoning or any other violent means.

Article 3: This group will have an ordinary meeting the first of each month and a special session whenever necessary. At the ordinary meetings all agreements reached will be valid regardless of the number of members present. At the special meetings, two-thirds of the group must be present, and all the members will be given ample notice of these meetings, so they will be able to attend them.

Article 4: At the ordinary sessions, every member will give an account of the way in which he carried out his retaliation, as well as the inconveniences and advantages of the method used. This will serve as a means of instruction to all other members. They will also discuss the reprisals still pending.

Article 5: Every member of the group must work out every possible method of arson, assassination, poisoning, that is to say, every means of causing damage. These will be submitted to the group for consideration.

Article 6: Special meetings will deal only with reprisals which are considered to be absolutely necessary. All members will be admitted to the ordinary meetings.

Article 7: Each member of the group is to pay one-twentieth of a peseta weekly for mailing expenses, and any remaining amount will be used as seen fit.

When expenses exceed existing funds, every individual must contribute from his own pocket, and in case of urgent need, we will ask the Federation for money.

Punishments that endanger the individual should be avoided, but every favorable opportunity which arises should be taken advantage of. When it is believed necessary to endanger one's life, it must be done with all one's zeal and with the use of any available weapon.

Cases where one should be prepared to risk one's life are when one has threatened someone by letter before the act has been committed, and the victim then proceeds to protect himself. In such cases, one must carry out one's threat so that it may not be fruitless.

Damage must be always done to property whenever there is no need of injuring people. 
No individual will be obliged to do more than he freely commits himself to, and even if he refuses to do something because he is not capable of it, he will not be forced to it, but he will be considered a traitor if he seeks the protection of this article to refuse to act at all. He will be considered worthless and will be expelled.

Expelled members must be kept under close watch and punished by death if discovered to have divulged anything.

A traitor is to be killed regardless of whether he is a friend, brother or father. He who risks many lives can never pay enough by losing his own.

If the local group cannot kill him either because everyone knows him or for some other reason, they will advise the group of another locality so that they may do it through someone who does not know him. ${ }^{1}$ But in this case, a signed and sealed order from the Secretary and the President of the locality where the death was prescribed and decreed is needed.

The secretaries are to have assumed names which will only be known among themselves, and provided that they sign with the assumed names, the letter will be acknowledged and made known to the group to which it is addressed. The secretaries will keep the seal in their possession. The president will sign the minutes of the meetings with his initials backwards. Such are regulations which must be observed.

The group will not be disbanded until social revolution has been achieved.

Those who become members of the society cannot leave even when they become property owners; they can only leave when they move to a village where there is no such group. But if there is one, he will enlist by means of a reference which he will be given from the group he is leaving.

The profits are common to the group and do not belong to specific individuals. They can be used as the group sees fit.

It is the duty of the members to propose reforms in the regulations in order to improve them, or to request the suppression of certain articles.

The group is not responsible for actions taken without previous agreement by it, unless it declares afterwards that the individuals have acted well and that it approves the action.

Whenever there is a vote against any act, no pressure can be put on the dissenting member, nor will he be held responsible for anything.

No one will discuss any action in public squares or in the streets,

1 It is difficult to determine the precise translation of this phrase into English. The exact meaning of the Spanish original is not clear and its syntax is rather obscure. 
unless it be among the members of the group, and only then provided that members speak as quietly as possible and at least forty paces away from anyone.

Also, in order to avoid spies, no one will talk about the society's business in the fields behind fences or walls.

When one is to perform an action, one should have a statement prepared beforehand in case of being caught or taken as a suspect. If caught in the act, one must also know beforehand how to make the $1^{\mathrm{a}}$ and in $\mathrm{T}$. [sic!]

When anyone has the opportunity to do $g^{0}$. $d^{\mathbf{a}}$., he will be able to $\mathrm{h}^{\mathbf{a}}$ without risk. ${ }^{1}$ The conduct to follow will be agreed upon in the first ordinary session to be held.

Both the group or any of its members can employ outsiders, even if they do not belong to it or to the Federation, to perform certain deeds, but the outsider must not be told about the organization.

Amendments to the regulations are to be presented at ordinary meetings and two-thirds of those present will determine the results.

Before an individual is admitted, the regulations will be read to him three or four times, and he will be given three days to either accept or reject them.

Upon entering, everyone will be given a different surname, and members will know each other by the new name, with which they will sign documents.

Surnames will be substituted by first names.

The duty of the member is to instruct their children and the workers in general to hate the rich and anybody who wishes to dominate them, or who puts himself above them and lives at the expense of other people's work.

An interesting excerpt from one of the documents [example given by the informant] :

Abominable exploiters. The day of popular justice is approaching: tremble, vile assassins. You want to force us to succumb to your brutal desires through hunger and we, amidst our poverty, have sworn revenge, and we will carry it out. It will be so horrible, that it will terrify the world, if first you do not abandon the infamous method you have adopted.

Let this be a warning, for we have built up a large stockpile of bombs and dynamite to blow up all the houses of the bourgeoisie if you refuse to obey our orders.

1 See p. 343 , note 1. 
Agreed upon at an extraordinary session of this vindictive executory Group.

According to inquiries carried out in September, 1882, the following are the villages in which there is the greatest number of socialists:

Jerez de la Frontera, Arcos de la Frontera, Sanlúcar de Barrameda, Ubrique, Tesarillo, Bornos, Paterna, Grazalema, Medina Sidonia, Setenil, Alcalá del Valle, Écija, Osuna, Carmona, Marchena, Arahal, Lebrija, Cazalla de la Sierra.

\section{Observations:}

1st: On observing the majority of crimes committed in this country and the endless number of malefactors apprehended by the Civil Guard, it can be easily understood that many of them are a result of the preceeding regulations.

2nd: On observing the majority of trials initiated and held by courts of primary jurisdiction for crimes such as setting fire to woods and forests and cutting down trees in them, injuries and murders, as well as those trials against individuals caught in fraganti sending anonymous letters requesting money, it will become evident that many of them have a direct link to the Society and its groups.

3rd: It is well known that the Civil Guard, contributing with the greatest zeal to individual safety of all persons and property, keeps a careful watch to prevent the actions and excesses to which the above mentioned regulations refer. This has been proven by the many arrests made because of anonymous letters requesting money, by the number of arsonists apprehended and by the other excesses uncovered.

4th: The Civil Guard also has the names of many socialists in their respective localities, and of some of those who cooperate extensively with them.

5th: Despite the precarious situation of the country, the Civil Guard has been able to preserve a certain peace in which the public order will not be altered, and has contributed both by its very existence and moral strength to stopping some strikes that have been started this year.

This is a copy.

The General Director

Tomás García Cerunio (Rubricated) 